\title{
A New Insight into the Biostratigraphy of Usfan and Haddat Ash Sham Formations, West Central Saudi Arabia
}

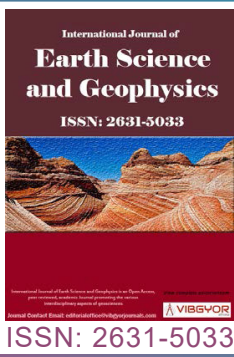

\section{Gameil ${ }^{*}$ AA Mesaaed and R Thiga}

Faculty of Earth Sciences, King Abdulaziz University, Jeddah, Saudi Arabia

\begin{abstract}
A clastic-dominated sedimentary succession is exposed in different localities at the central part of western Saudi Arabia, unconformably overlying the weathered Precambrian Arabian Shield rocks. The age and chronological relationships of the different formational names applied to that succession is still a matter of debate among geologists. The succession is assigned to Cretaceous-Eocene or Oligo-Miocene according to the ages of the overlying Tertiary basic volcanics (harrat).

Field study of the paleontological and biostratigraphical characteristics of the two formations, namely Usfan and Haddat Ash Sham; show that they are chronologically equivalent. The fauna of both formations is dominated by bivalves and gastropods but they are more common in Usfan than in Haddat Ash Sham Formation.

The first record of the Radiolitids Eoradiolites liratus (Conrad) that is common in the Albian-Turonian strata of Egypt, Morocco, Somalia and Algeria, and the neritid gastropod Nerinea coquandiana d'Orbigny which is common in the Aptian-Cenomanian strata of southern France, Spain, Portugal, Italy, Lebanon, North Africa and Somalia, as well as the nautiloid Angulithes mermeti (Coquand) which is characteristic to the Upper Cenomanian of Tunisia, Egypt and Spain testifies a Cenomanian-Turonian or at most an Upper Cretaceous age for the studied two formations.
\end{abstract}

\section{Keywords}

Mollusca - Gastropods - Bivalves, Upper Cretaceous - Cenomanian/Turonian - Marine - Biostratigraphy

\section{Introduction}

A sedimentary succession dominated by clastics rests nonconformably on the basement rocks of the Arabian Shield at the west central part of Saudi Arabia. The succession has been given different formational names (Usfan Formation, Haddat Ash Sham Formation, Shumaysi Formation and Umm Himar Formation) in different localities, Karpoff $[1,2]$. It has also been given different ages
(Cretaceous - Eocene or Oligo-Miocene) according to the ages of the overlying Tertiary basic volcanics (harrat). The present work is concerned with studying the chronological relationship of Usfan and Haddat Ash Sham formations. The selection of the two formations is due to several reasons: Firstly they are the nearest similar formations particularly in biofacies characteristics; secondly the controversy in age assignment among the previous authors and thirdly the absence of a

*Corresponding author: M Gameil, Faculty of Earth Sciences, King Abdulaziz University, 80206, Jeddah, Saudi Arabia

Accepted: January 17, 2022; Published: January 19, 2022

Copyright: (c) 2022 Gameil M, et al. This is an open-access article distributed under the terms of the Creative Commons Attribution License, which permits unrestricted use, distribution, and reproduction in any medium, provided the original author and source are credited.

Gameil et al. Int J Earth Sci Geophys 2022, 8:056

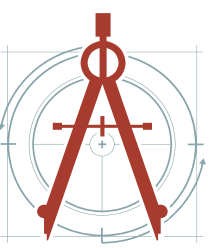


detailed paleontologic study for the macrofauna preserved in both formations. On the other hand, the succession known as the Shumaysi Formation is rich in economic iron ores $[3,4]$. It yielded few marine but many freshwater molluscan [5] and is assigned a younger age (early Eocene) than Usfan and Haddat Ash Sham formations (Cretaceous - Eocene or Oligo-Miocene). The lithofacies and biofacies aspect of the Shumaysi Formation is completely different than that of Usfan and Haddat Ash Sham formations. Moreover, its paleoenvironment was interpreted as being deposited in continental (fresh water) to estuarine environment [6]. The succession known as the Umm Himar Formation is also lithologically and paleontologically different. It rich in vertebrate fossils (shark teeth, catfish, lung fish, turtles and crocodiles), it was deposited in an estuarine environment and is assigned a Paleocene age [7].

The main concern of the present study is to propose a new age for Usfan and Haddat Ash Sham formations and correlate them biostratigraphically.

\section{Location and Geology of the Study Area}

The Haddat Ash Sham and Usfan areas are located in the west central part of Saudi Arabia NE of Jeddah City in Makkah district. The Haddat Ash Sham area lies about $70 \mathrm{~km} \mathrm{NE}$ of Jeddah city, it lies between latitudes $21^{\circ} 43^{\prime}$ to $21^{\circ} 55^{\prime} \mathrm{N}$ and longitude

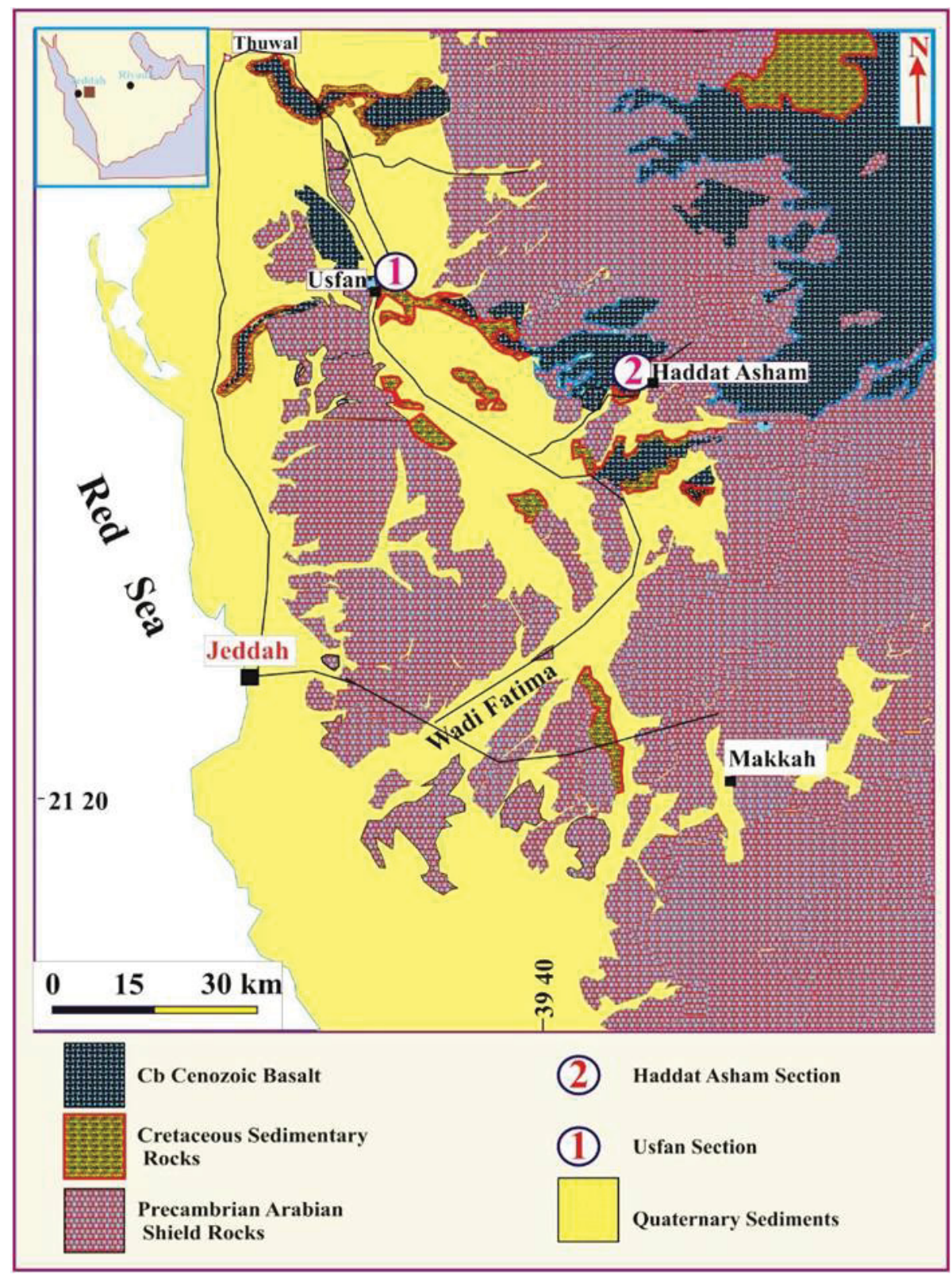

Figure 1: Geologic map showing the location of the studied areas (modified after Taj [9]). 
$39^{\circ} 33^{\prime}$ to $39^{\circ} 35^{\prime} \mathrm{E}$. The Usfan area lies about 90 $\mathrm{km} \mathrm{N}$ to NE of Jeddah city, it lies between latitudes $21^{\circ} 56^{\prime}$ to $21^{\circ} 58^{\prime} \mathrm{N}$ and longitude $39^{\circ} 19^{\prime}$ to $39^{\circ} 22^{\prime} \mathrm{E}$. The Usfan area is about $30 \mathrm{~km}$ west of Haddat Ash Sham area.

The area comprises the following main rock units (I) Older Pre-Cambrian igneous and metamorphic rocks of the Arabian shield; (II) sedimentary succession comprising the economic iron ores and clays deposits and the carbonate beds (the aim of the present study); (III) Tertiary basic volcanics (Harrat); (IV) Quaternary deposits (Figure 1).

\section{Materials and Methods}

Several field excursions were carried out to the study area. The strata in both sections (Haddat Ash Sham and Usfan) were described from their lithofacies and biofacies aspects. Fossils were collected from the carbonate and marly layers, they are dominated by bivalves with fewer gastropods and cephalopods. Fossils are described and identified at generic and specific level and compared with those known from other countries.

\section{Lithostratigraphy}

\section{Usfan formation}

The type locality of this formation lies near Usfan village. The Formation measures about 180 $\mathrm{m}$ in thickness. The formation is characterized by its carbonate ledge and has been divided into three members [8]: A lower, middle and an upper member. The lower member consists of shale, mudstone, marlstone, sandstone, limestone and dolomite. The middle member rests conformably

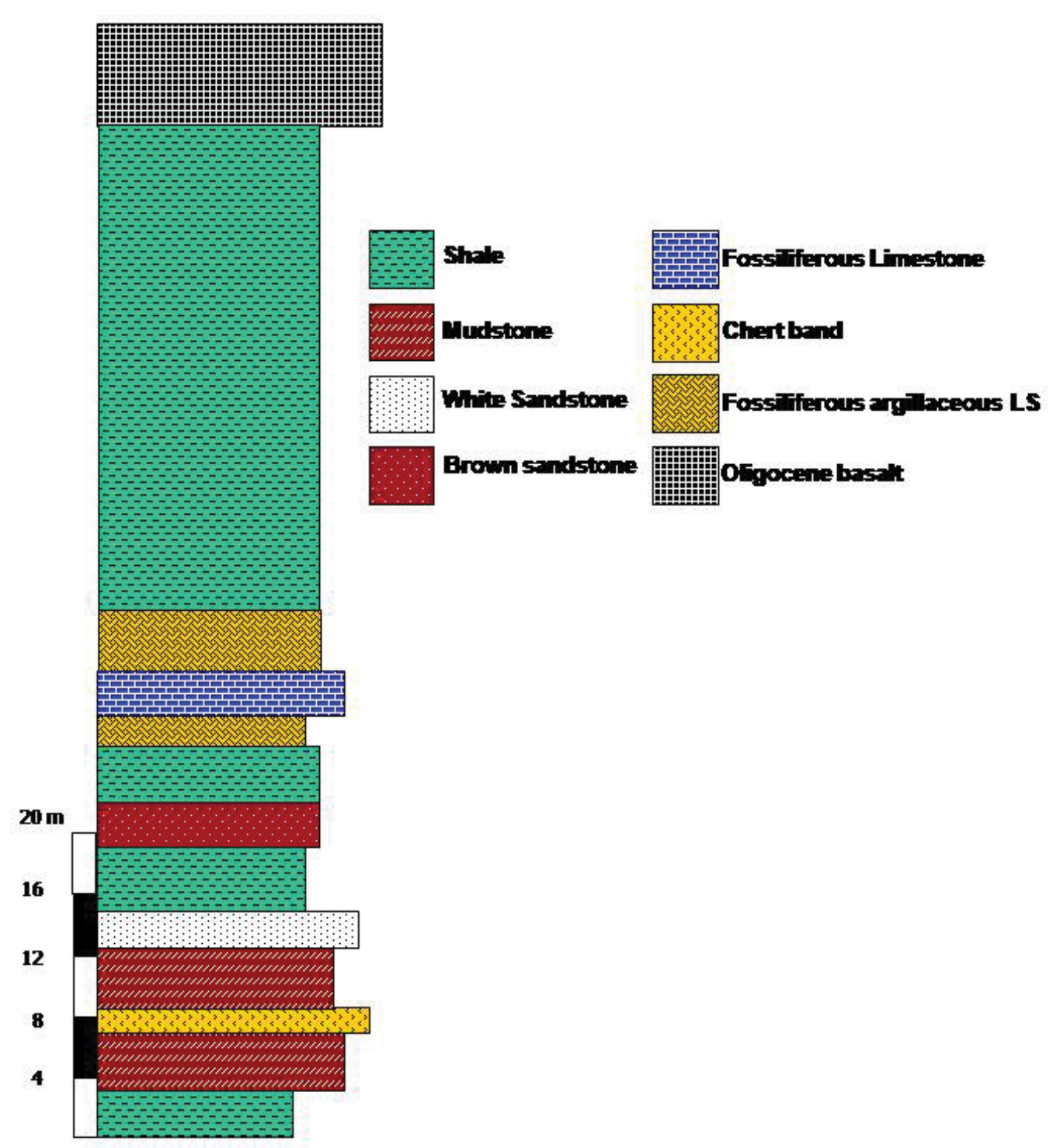

Figure 2: Lithologic log of Usfan Formation in Usfan Area. 
on the lower one with a $25^{\circ}$ dip to the northeast. It consists of very fine-to-fine quartz sandstone and an upper part of conglomerate layers. Planar parallel lamination and bioturbation are common in the lower and upper members. Thick units of shale with marked fissility and planar lamination form an important thickness of this sequence. Fine planar and wavy laminations are common. The upper member is covered by almost horizontal sheets of basaltic lava flows.

The Usfan Formation starts with $2 \mathrm{~m}$ of greenish yellow shale that contains thin laminae of hematite. This shale is followed by $2 \mathrm{~m}$ of dark brown ferruginous hematite mudstone that is overlain by a thin yellowish brown chert band. The chert is followed upward by yellowish brownish hard mudstone which is overlain by alternating grayish white friable sandstone and yellow, pink, green and grayish white shale, $6 \mathrm{~m}$ in thickness. The shale is glauconitic and containing phosphorite nodules (Figure 2).

The first fossiliferous bed in Usfan Formation is composed of friable yellowish brown soft phosphatic argillaceous limestone that is rich in large sized bivalves belonging to Venericardiids. This brownish soft limestone is overlain by the main fossiliferous limestone bed of Usfan Formation. This carbonate bed is easily distinguished in the field by its occurrence as a vertical cliff that looks like a wall of an ancient city and by its white color among the reddish and grayish colors of the underlying and overlying clastic units (Figure 3: 1-2).

The carbonate wall is rich in bivalves, turritellid gastropods, nautiloids and rudists (Figure 3 ). Its topmost part is composed of earthy white algal balls with phosphatic nodules and is overlain by another argillaceous limestone rich in bivalves and few nautiloids.

The upper clastic units are represented by Alternating layers of grayish green shale and brown sandstone that contain no fossils. This upper part contains black shales and light-colored siltstones interbedded with kaolinitic sandstones, coals, wood fragments and Oolitic ironstones. Oolitic ironstones are a characteristic feature of the Usfan formation and are considered to form a regionally correlative stratigraphic layer near the top of the marine section [4]. These clastics are covered by the Oligocene basaltic flows that are widespread in the area.
The presence of glauconite and phosphate beds in Usfan Formation led Karpff [1] to assume that the formation was deposited in littoral to shallow marine environment.

\section{Haddat ash sham formation}

The Haddat Ash Sham Formation outcrops at its type locality Haddat Ash Sham village, about $60 \mathrm{~km}$. northeast of Jeddah. It measures about $480 \mathrm{~m}$ in thickness. The sedimentary sequence of Haddat Ash Sham Formation consists of clastic rocks dominated by sandstones, shales, mudstones, oolitic, ironstones, and occasionally conglomerates. The formation has been divided into three members [8]: A lower, middle and an upper member. The lower member rests non-conformably on Precambrian rocks and is clearly visible in the southernmost part of the study area where it is marked by a basal conglomerate. The middle member overlies the lower member conformably. The upper member rests conformably on the middle member. It is characterized by finer grained sediments mainly shale and siltstone with a minor proportion of very fine to fine- grained sandstone. The member is terminated by a $1 \mathrm{~m}$ thick bed of red shale.

The Haddat Ash Sham Formation starts with $7 \mathrm{~m}$ of slope forming black shale which is overlain by chocolate white fine grained sandstone. This sandstone is followed upward by black shale and hard thinly laminated brown mudstone. Yellowish brown, shale containing dark brown oolitic ironstone and red beds overlies the hard mudstone and is overlain by earthy white fine grained calcareous sandstone. A bed of about $4 m$, composed of yellowish brown to gray shale, ends that clastic cycle. All these beds are barren of fossils (Figure 4).

The first fossiliferous bed of Haddat Ash Sham Formation is an egg yellow dolostone, one meter thick with rare fossils. The dolostone is overlain by grayish white limestone bed two meters thick. This limestone is rich in highly condensed venericardia bivalves together with other bivalves and gastropods. No nautiloids are recorded in Haddat Ash Sham Formation. It is followed by another fossiliferous egg yellow to brown dolostone, one meter thick, where fossils are fewer than the underlying limestone bed (Figure 3: 3-4). The fossiliferous limestone and dolostone beds are again followed upward by clastic deposition 


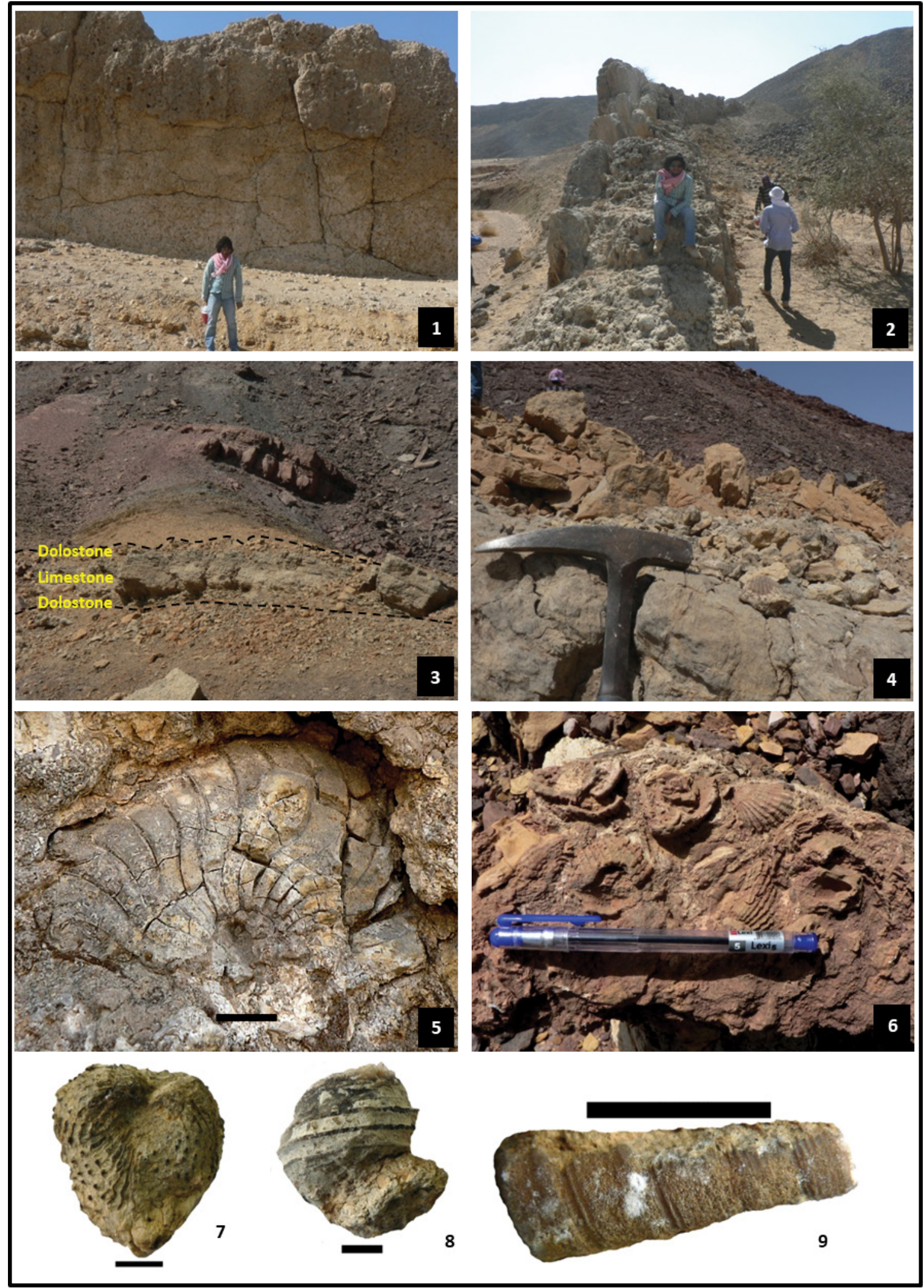

Figure 3: 1- Vertical carbonate wall and the underlying yellow phosphatic marly Limestone of Usfan Formation. 2- Strike view showing the thickness of the carbonate wall of Usfan Formation. 3- Fossiliferous limestone sandwiched between two thin dolostone beds of Haddat Ash Sham Formation. 4- Upper part of the limestone and the overlying egg yellow dolostone with a thin Venericardia bed in between. 5- A piece of rock rich in Venericardia sp. 6- The nautiloid Angulithes mermeti from the carbonate wall of Usfan Formation. 7- Shell of Venericardia sp. 8, 9- Incomplete shells of Turritellid gastropods. 
of alternating greenish gray and dark gray slope forming shale and brown bioturbated fractured sandstone that form the remaining thickness of Haddat Ash Sham Formation. These clastic cycles are also barren of fossils.

One can summarize the lithostratigraphy of Haddat Ash Sham Formation as being composed of thin fossiliferous carbonate beds sandwiched between shales, mudstones and sandstones below, and alternating shales and sandstones above. The study of the microfacies and diagenesis of the Haddat Ash Sham Formation led Taj [9] to assume that the formation was deposited in lagoonal to fluvio-lacustrine environment.

\section{Biostratigraphy}

The fossiliferous carbonate unit of Usfan Formation attains up to $3 \mathrm{~m}$ thick and consists mainly of white color cliff-forming fossiliferous limestone with very thin yellow color dolostone interbeds. The carbonate unit is rich in shell and shell fragments of bivalves, gastropods and few nautiloids (Figure 3: 5). It is underlain and overlain by yellowish brown soft phosphatic marls that are also rich in shells and shell fragments of bivalves, gastropods and nautiloids that can be obtained easily as free specimens.

Fossils of Usfan Formation are distributed in three assemblage biozones (Gameil, et al. in Preparation); the first assemblage biozone coincides with the lower argillaceous limestone bed and contains many bivalve species belonging to Lucina fallax, Lucina sp., Sphaera cf. corrugate, Venericardia forgemoli, Venericardia spp., Granocardium carolinum and the gastropod Turritella sp.

The second assemblage biozone coincides with the main carbonate cliff and contains bivalves belonging to Nucula (Nucula) margaritifera, Modiolus (Modiolus) safrensis, Eoradiolites liratus, Lucina sp., Sphaera cf. corrugate, Venericardia

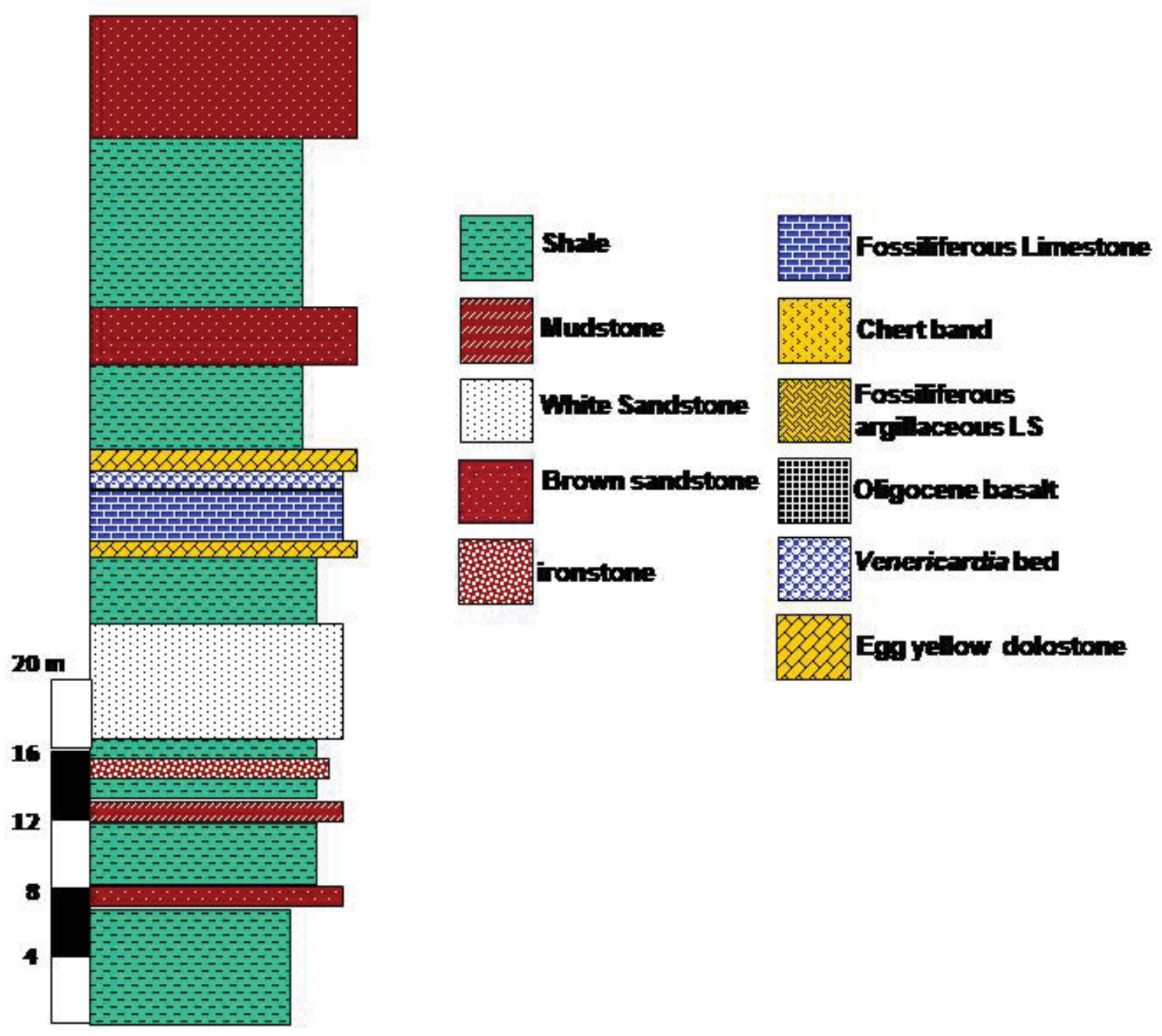

Figure 4: Lithologic log of Haddat Ash Sham Formation in Haddat Ash Sham Area. 


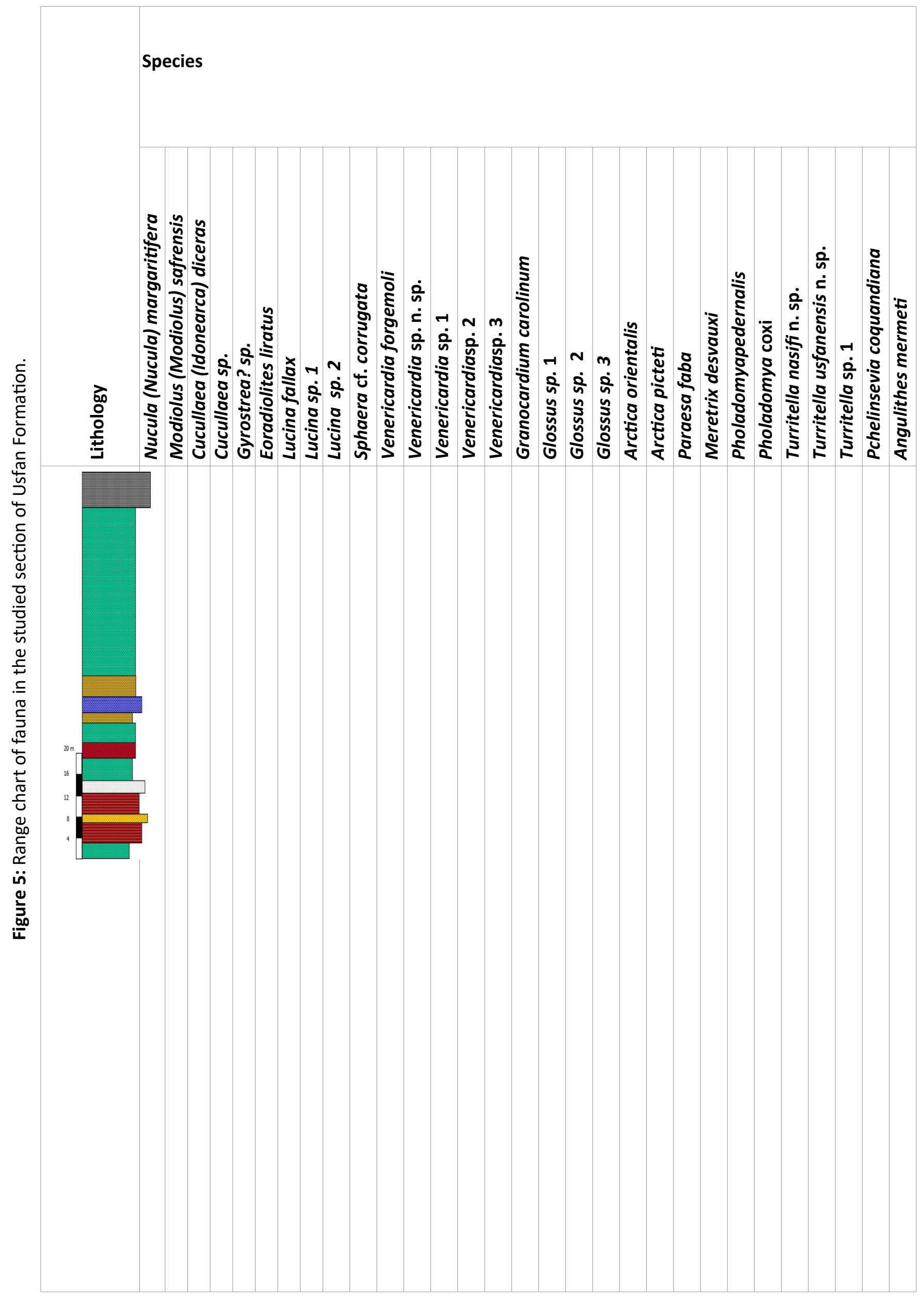


forgemoli, Venericardia spp., Granocardium carolinum, Glossus spp., Arctica picteti, Paraesa faba, Meretrix desvauxi, Pholadomya pedernalis. It contains also three gastropod species belonging to Turritella nasifi n. sp., Turritella usfanensis $\mathrm{n}$. $\mathrm{sp}$. and Pchelinsevia coquandiana. The nautiloid Angulithes mermeti is recorded in this horizon.

The third assemblage biozone coincides with the upper argillaceous limestone bed above the carbonate cliff and contains bivalves belonging to Cucullaea (Idonearca) diceras, Cucullaea sp., Gyrostrea?sp., Venericardiaforgemoli, Venericardia sp. n. sp., Venericardia spp., Granocardium carolinum, Glossus sp., Arctica orientalis and Pholadomya coxi. The nautiloid Angulithes mermeti recorded in the previous biozone exists also in this

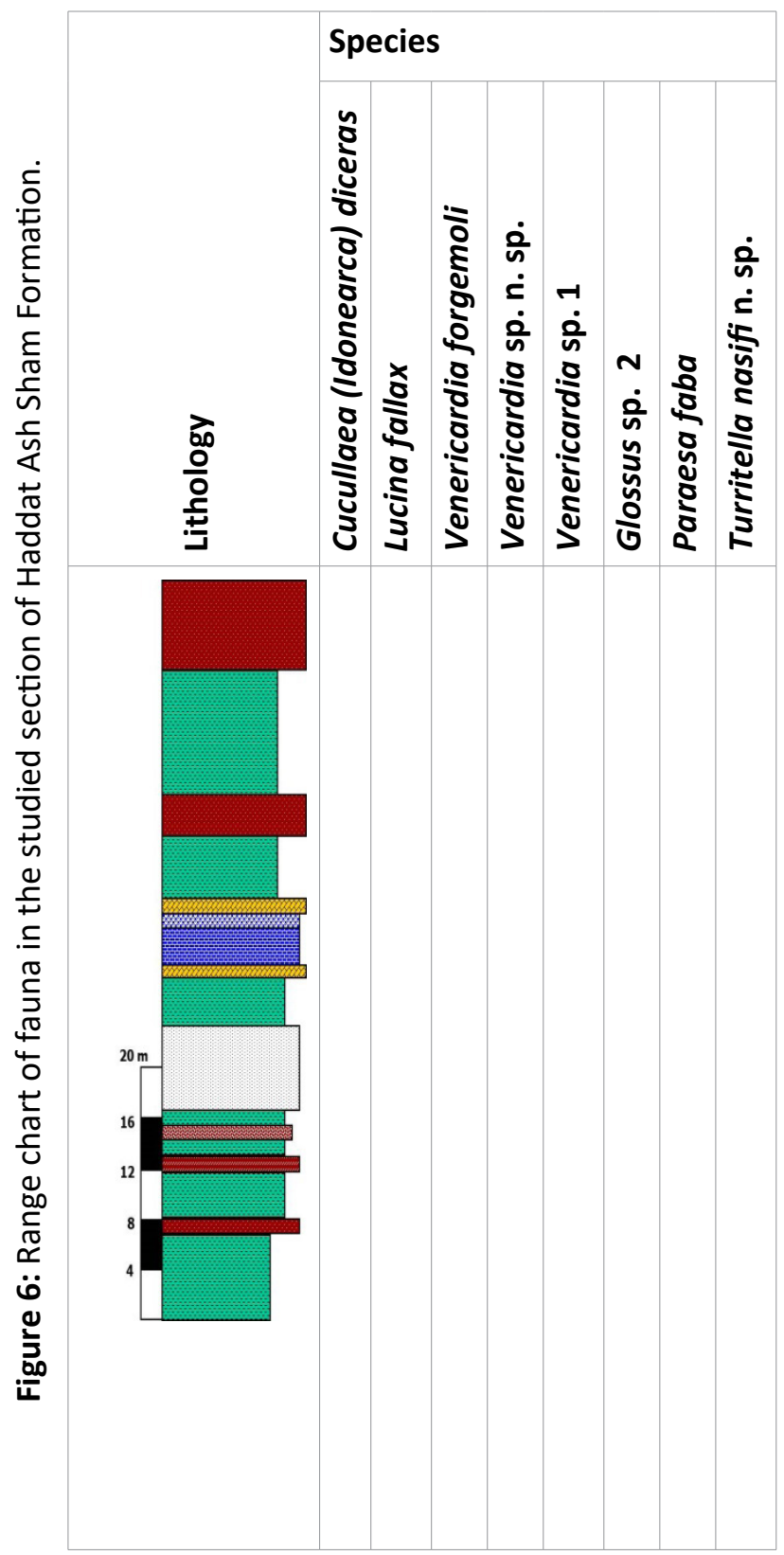

biozone where free specimens could be collected. Distribution of this fauna in the section is shown in Figure 5.

On the other hand, the fossiliferous carbonate unit of Haddat Ash Sham Formation attains up to $2 \mathrm{~m}$ thick. It is rich in bivalves of Cucullaea (Idonearca) diceras, Lucina fallax, Glossus sp. 2, Paraesa faba and Turritellid gastropods (Figure 3: 8-9). The overlying Venericardia bed is rich in Venericardia forgemoli, Venericardia sp. n. sp. and Venericardia sp. 1. (Figure 3: 6-7). Distribution of this fauna in the section is shown in Figure 6. Some of the identified fossils from both Usfan and Haddat Ash Sham formations are photographed in Figure 7.

\section{Age Assignment}

The age of Usfan Formation has been and still is a matter of controversy among different authors. Karpoff [1] first assigned as late Maastrichtian to Eocene age based on molluscs and shark teeth. Coxcin in [4] assigned an early Eocene age based on molluscan. Brown [10] dated a glauconitic bed beneath the "Great Wall" limestone as 43-55 Ma using K-Ar dating, although he suspected that this may be an anomalously young age due to the poor quality sample. Basahel, et al. [11] identified some baluchicardid molluscs and nautiloids from a phosphatic bed in the lower part and assigned a Maastrichtian-Paleocene age to the formation. Moore and Al-Rehaili [12] assigned Paleocene to Early Eocene age based on the Stratigraphic position. Abou Ouf and Gheith [13] state that radiometric and biostratigraphic evidence indicate that the Usfan Formation is clearly of Maastrichtian to Eocene age (Table 1).

Basahel, et al. [11] mentioned the occurrence of Turretellid gastropods (without giving any figures) which they named Turritella (Torquesia) nazikae Awad and Abed, 1967 and T. (Torquesia) saharica Awad and Abed [14] that are identified from the Paleocene of Egypt (see Abbass [15]). In fact Turritella (Torquesia) nazikae has smooth surface sculpture and each whorl imbricate posteriorly over the preceding whorl. All identified turritellid species from Usfan and Haddat Ash Sham have surface sculpture and not smooth and consequently belong to other species. On the other hand Turritella (Torquesia) saharica has three primary spiral cords on each whorl in addition to one secondary spiral cord between the posterior two cords and another 
Table 1: Age assignments for Usfan Formation by previous authors and the present work.

\begin{tabular}{|l|l|l|}
\hline Author & Age & Tools used \\
\hline Karpoff [1] & Late Maastrichtian - Eocene & Molluscs and shark teeth \\
\hline Al-Shanti [4] & early Eocene & Mollusca \\
\hline Brown [10] & 43-55 Ma (Eocene) & K-Ar dating \\
\hline Basahel, et al. [11] & Maastrichtian & Nautiloids and bivalves \\
\hline Moore and Al-Rehaili [12] & Paleocene to Early Eocene & Stratigraphic position \\
\hline Abou Auf and Gheith [13] & Maastrichtian to Eocene & Radiometric and Biostratigraphic evidence \\
\hline Present work & Cenomanian-Turonian & Molluscs \\
\hline
\end{tabular}

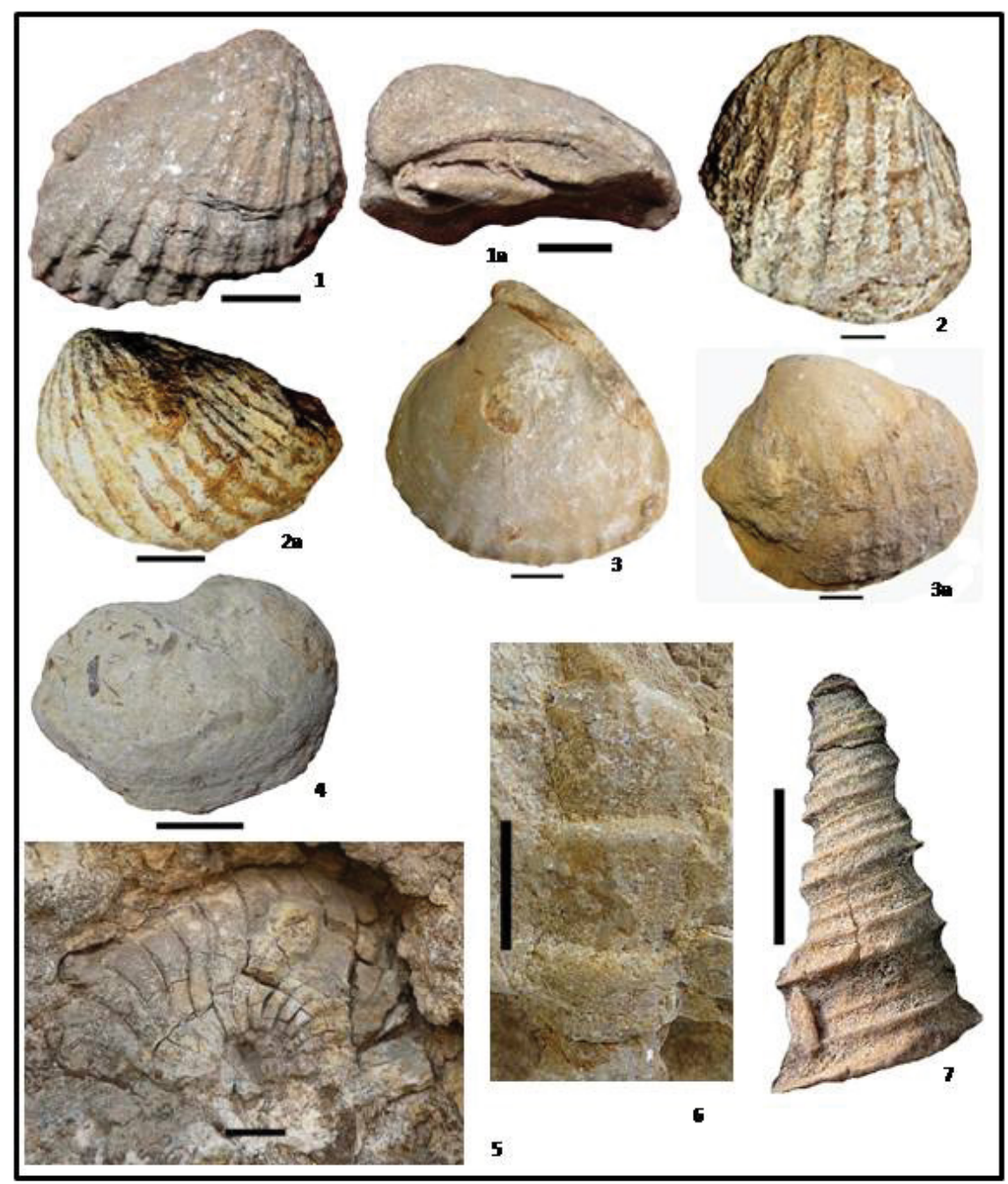

Figure 7: Some of the species identified from the study area. 1: 1a: Venericardia sp; 2: 2a: Glossus sp; 3: 3a: Arctica orientalis [21]; 4: Pholadomya pedernalis [22]; 5: Angulithes mermeti [17]; 6: Eoradiolites liratus [18]; 7: Turritella sp.

secondary spiral cord lies in the posterior area between the suture and the posterior primary cord. That means that each whorl has five spiral cords, three primary, and two secondary. In the studied turritellids one species has two primary cords and two to three secondary anterior spiral cords on each whorl without spiral cords in the interspaces between the primaries, the other species has three primary spiral cords without secondary cords.

Moreover, Basahel, et al. (op.cit) identified the abundant venericardiid specimens as belonging to one species namely Baluchicardia beamonti [16] which occurs in the Paleocene of Egypt. In fact 


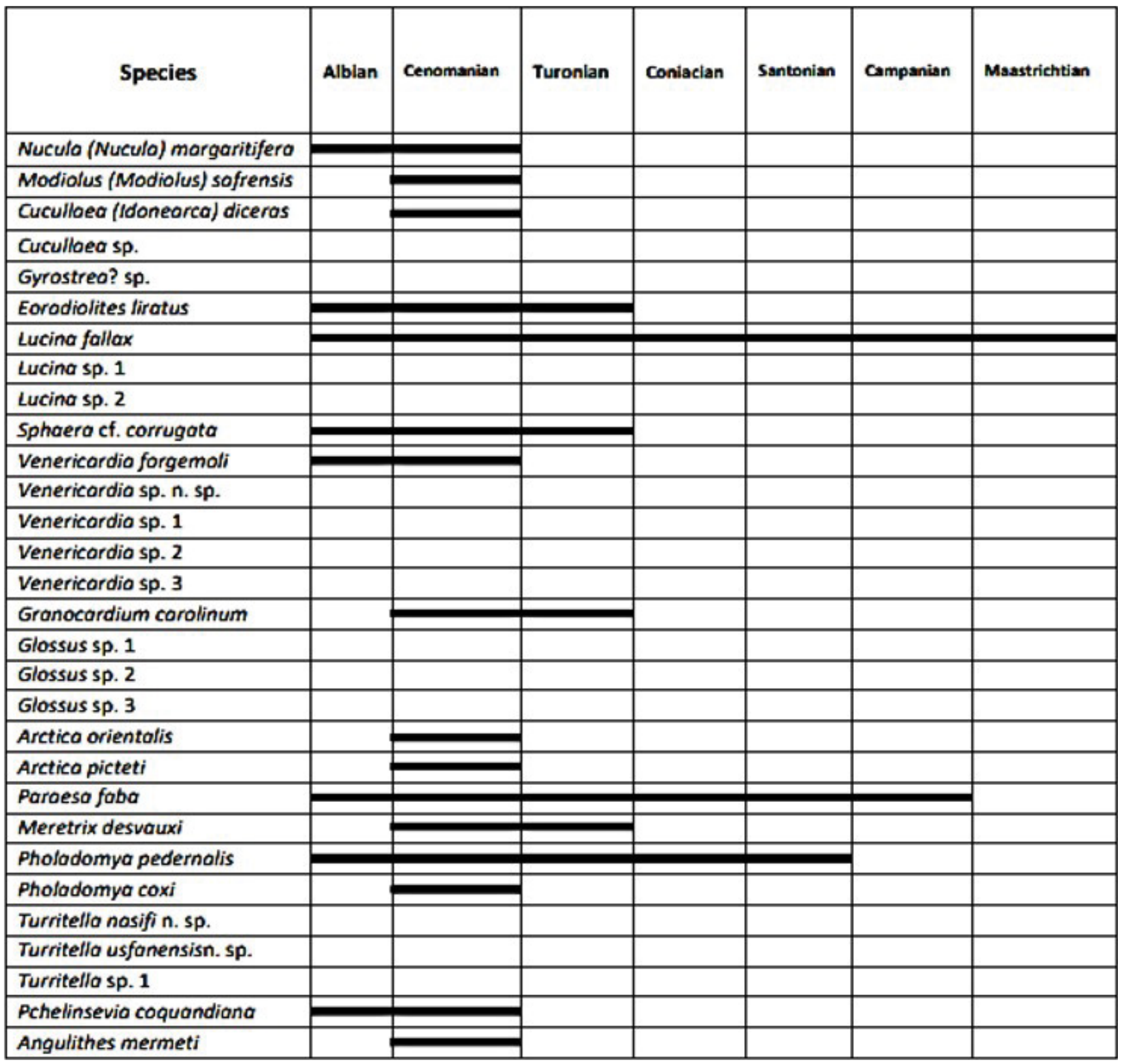

Figure 8: Stratigraphic range of the identified species.

Baluchicardia beamonti defined from the Egyptian Paleocene strata is ornamented by tripartite radial ribs of which the median one is the strongest and carries rounded tubercles near the umbo. These tubercles change into transversely elongate ridges near the ventral margin. The Usfan and Haddat Ash Sham specimens that have tripartite ribs have no tubercles characteristic for Baluchicardia beamonti and are here assigned to Venericardia sp. Some other specimens have tubercles but the ribs are single not tripartite, and the tubercles don't change into transversely elongate ridges near the ventral margin as in Baluchicardia beamonti. One concludes that Baluchicardia beamonti doesn't exist in Usfan and Haddat Ash Sham bivalves and hence a Paleocene age is excluded. Moreover venericardiids of the study area seem to belong to several species and not one species.

The authors also mentioned the occurrence of two nautiloid species Cymatoceras sakalaous (Collignon) and Cimomia whylliei Newton, these two nautiloids are of Maastrichtian age. Accordingly, those authors considered the lower clastic horizon with the nautiloids as of Maastrichtian age and the algal limestone horizon with venericardiids and turritellid gastropods as of Paleocene age.

Actually nautiloids don't occur only in the phosphatic marly bed below the carbonate cliff as Basahel, et al. (op. cit.) mentioned, but they occur 
in the main carbonate bed and also in the marly bed above the carbonate cliff. The specimens they found may have been reworked and fallen from the upper marly bed above the carbonate cliff. Moreover all nautiloid specimens are identified according to their morphological characteristics as belonging to one species namely Angulithes mermeti [17] which is characteristic to the Upper Cenomanian of Tunisia, Egypt and Spain.

In the present study, it has been noted that most of the fauna are common in the Cenomanian Turonian strata of Egypt, Libya, Tunisia, Algeria and Morocco, the Stratigraphic range of the identified species is shown in Figure 8. Accordingly, the present work assigns a Cenomanian-Turonian age for Usfan and Haddat Ash Sham formations. The presence of the rudistid Eoradiolites liratus [18] and the nereinids Pchelinsevia coquandiana [19] which died out at the end of Cretaceous confirms at most an Upper Cretaceous age for the two formations. The occurrence of the nautiloid cephalopod Angulithes mermeti [17] which is associated with Neolobites vibrayanus Zone in North Africa (Egypt, Libya, Tunisia, Algeria and Morocco) also supports an Upper Cretaceous age [20].

\section{Conclusion}

The encountered molluscan fauna in Usfan and Haddat Ash Sham formations and their distribution show that there is a great similarity in the biostratigraphical aspects of Usfan and Haddat Ash Sham formations, where fossils exist in a carbonate unit sandwiched between clastic strata of greater thickness. The molluscan species are similar in both areas, but they are more common in Usfan than in Haddat Ash Sham area.

Biostratigraphic evidences especially the occurrence of the rudistid Eoradiolites liratus [18] and the nautiloid cephalopod Angulithes mermeti [17] which are common in the CenomanianTuronian strata of North Africa supports a Cenomanian-Turonian age for Usfan and Haddat Ash Sham formations.

The nautiloid Angulithes mermeti is found in Usfan formation but absent in Haddat Ash Sham Formation due to the dominance of shallower or lagoonal conditions. The lithologic and paleontologic criteria confirm the deposition of Usfan strata in proper marine conditions than that dominated in the lagoonal environment of Haddat
Ash Sham area. The presence of glauconite and phosphate beds in Usfan confirms the obtained results.

\section{Acknowledgement}

The authors are thankful to the Faculty of Earth Sciences administration for providing the necessary requirements to carry out field investigations and samples collection to do this research.

\section{References}

1. Karpoff R (1957) Sur l'existence du Maestrichtiane au Nord de D Jeddah Arabia Seoudite. Compt Rend Séance Acd Science 245: 1322-1324.

2. Karpoff R (1958) Esquisse geologiques de L'Arabie Saoudite. Bulletin Societe Geologique de France 6S-VII: 653-696.

3. Richter-Bernaurg R, Schott W (1954) Geological researches in western Saudi Arabia. Saudi Arabian General Directorate of Mineral Resources.

4. Al-Shanti AMS (1966) Oolitic iron ore deposits in Wadi Fatima between Jeddah and mecca, Saudi Arabia. Saudi Arabian General Directorate of Mineral Resources Bulletin 2: 51.

5. Abbass HL (1971) Two new Saudi Arabian Oligocene freshwater gastropods. Ain Shams Bulletin 15: 77-85.

6. Molzer JG, Binda PL (1981) Micropaleontology and palynology of the middle and upper members of the Shumaysi formation, Saudi Arabia. Bulletin of Faculty of Earth Sciences 4: 57-67.

7. Madden $C T$, Whitmore FC, Schmidt DL, Langston $W$, Wood RC (1979) Paleocene vertebrates from coastal deposits in the Harrat Hadan Area at Taif Region, Kingdom of Saudi Arabia. US Geological Survey, Project Report, General Directorate of Mineral Resources.

8. Zeidan R, Banat K (1989) Petrology, mineralogy and geochemistry of the sedimentary formations in Usfan, Haddat Ash-Sham and Shumaysi Areas, and their associated oolitic ironstone interbeds, north east and east of Jeddah, Saudi Arabia. Directorate of Research Projects, King Abdulaziz University, Saudi Arabia.

9. TajRJ (2013) Microfacies, diagenesis, and depositional environments of the Tertiary carbonates of Usfan Formation in Haddat Ash Sham area, Western Arabian Shield, Saudi Arabia, Saudi Society for Geosciences. Arab Journal of Geosciences 6: 1011-1031.

10.Brown GF (1970) Eastern margin of the Red Sea and coastal structures in Saudi Arabia. Philosophical 
Transactions of the Royal Society of London A 267: 75-87.

11.Basahel AN, Bahafzallah A, Jux U, Omara S (1982) Age and structural setting of a Proto-Red Sea embayment. Neues Jahrbuch für Geologie und Palöntologie $\mathrm{MH}$ 1982: 456-468.

12.Moore TA, Ar-Rehaili H (1989) Geologic map of the Makkah quadrangle, sheet 21D, Kingdom of Saudi Arabia. Geoscience Map, Saudi Arabian Deputy Ministry for Mineral Resources.

13.Abou Ouf M, Gheith AM (1998) Paleo-environmental interpretation of synrift and prerift sediments of the eastern flank of the central Red Sea, Jeddah RegionSaudi Arabia. Arab Gulf J Scieni Res 15: 275-307.

14.Awad GH, Abed MM (1967) Biostratigraphical zoning of the lower Tertiary in the Dakhla Oasis. Geological Survey of Egypt.

15.Abbass HL (1967) A monograph on the Egyptian Paleocene and Eocene gastropods. Geological Survey, Paleontological Series, Monograph 4: 1-154.

16.Archiac Ad', Haime J (1853) Description des animaux fossils du Groupe Nummulitique de I'Inde. Précédé d'un résumegéologique et d'unemonographie des nummulites, Paris, 3.
17. Coquand MH (1862) Géologie et Paléontologie de la régionsud de la Province de Constantine. Mémoires de la Sociétéd'Émulation de la Provence 2: 1-341.

18.Conrad TA (1852) Description of the fossils of Syria, collected in the Palestine expedition. In: Lynch WF, Official report of the United States expedition to explore the Dead Sea and the River Jordan. Murphy and Co, Baltimore, US, 235.

19.Orbigny AD d' (1842) Paléontologie française: Description zoologique et géologique de tous les animaux Mollusques et Rayonnés fossiles de France. Terrains Crétacés.

20.Nagm EH (2009) Integrated stratigraphy, palaeontology and facies analysis of the Cenomanian - Turonian (Upper Cretaceous) Galala and Maghra El Hadida formations of the western Wadi Araba, Eastern Desert, Egypt. Universität Würzburg, Germany.

21. Hamlin CE (1883) Results of an examination of Syrian Molluscan fossils, chiefly from the range of Mount Lebanon. Memoirs of the Museum of Comparative Zoology at Harvard College, Cambridge, 10.

22. Roemer $F$ (1852) Die Kreidebildungen von Texas und ihre organischen Einschlüsse. Bonn, Germany, 100. 